\title{
Memories of Miles - Miles Blackwell and his contribution to South African librarianship
}

\author{
A.S.C. Hooper \\ School of Information Management, Victoria University of Wellington, New Zealand \\ Tony.Hooper@vuw.ac.nz \\ J.H. Viljoen ${ }^{2}$ \\ Stellenbosch University, South Africa \\ jhvi@sun.ac.za
}

Received: I July 2010

Accepted: II November 2010

\begin{abstract}
The contribution of BH Blackwell (BHB), and specifically of Miles Blackwell, to the development of libraries and librarians in South Africa is explored based on available literature sources and personal reminiscences. This article tells how Miles was true to his personal values and how he demonstrated his integrity in the exercise of his office. Miles integrated in his mind the history of the "firm" of BHB and the times that it lived though with his sense of his responsibility to his customers. He was prepared to stand up against enormous political pressure from his peers in Europe and North America, and perhaps his fellow board members in BHB, to make sure that the channels of published information flow remained open to his customers in South Africa. The value of books and information was what he believed in. His service to his customers in South Africa reflected the self-sacrificing service ethic that he understood to be the essence of the family firm of which he had the great privilege of leading. He contributed to the development of the new, post-apartheid South Africa by ensuring that the people who needed the enlightened word to become part of the global society, benefited by what he had done.
\end{abstract}

Keywords: Blackwell Travel Bursary; library book trade; Miles Blackwell; South African librarianship

\section{Introduction}

The sudden and early demise of Miles Blackwell in 200 I left a relationship gap that the nostalgic memories of some of his 'chums' are inadequate to fill. One summer evening in 2009 in Stellenbosch, under circumstances in which Miles would have felt very much at home, the authors decided to gather memories of Miles Blackwell and to record what he had contributed to libraries in South Africa during his 12 year tenure as head of BH Blackwell (BHB) from 1985 until his retirement in 1997. Miles' business made him aware of the stature of South African librarianship, and the important role that libraries played in the apartheid years to bring knowledge and enlightenment to all the people of South Africa. In accordance with his beliefs and values, he contributed greatly to the development of quality library services in South Africa through encouraging the growth of libraries and of the library profession. After some consideration, it was realised that the involvement of Peter May would be an important source of information and insight for such a contribution. Accordingly, he was contacted and, after consultation with relevant colleagues at BHB, agreed to contribute to this article. Similarly, Don Satisky, representative for Blackwell North America for many years, agreed to contribute his reminiscences of Miles Blackwell during their visits to South Africa. The authors are indebted to them both. This article is intended to be a tribute to a man who, in a quiet, self-effacing and low-key manner, characteristic of his personal style, demonstrated in practical ways his concern for South Africa and the well-being of his customers.

\section{BHB - Booksellers to the world}

It is not the intention to provide a history of the company in this article. It is necessary, however, to place BH Blackwell in the context of its time and situation as a means to understand the circumstances in which the main subject of this article, Miles Blackwell, was to spend the significant period of his career.

BH Blackwell was started on Ist January 1879, eleven days before the beginning of the Anglo-Zulu War (Ricketts and Foster 2004: 2). On 22 January 1879, the British Army sustained a serious defeat with the massacre at Isandhlwana. Surviving troops fled, warning the small supply contingent at Rorke's Drift mission station of the advancing Zulus seeking to 'wash their spears' in the blood of survivors. More Victoria Crosses (the highest British award for valour) were

I. A.S.C. Hooper is in the School of Information Management at Victoria University of Wellington where he has served as Programme Director of the Master of Information Management and currently as Director of Teaching and Learning. Previously, he was University Librarian and Director of Libraries at the University of Cape Town - from 1980 to 1997. He also served as President of SAILIS.

2. Hennie Viljoen (PhD) is Professor Emeritus at Stellenbosch University. He was the Director of Libraries at the University of Stellenbosch for many years. He also served as President of SAILIS. 
awarded for the defence of Rorke's Drift that night than for any other battle, before or since. This dramatic story of British arms, particularly as it occurred at a significant time in the history of his family, would have been of compelling interest to Miles. Perhaps the association with historic events and the highest values and motives of British tradition helped shape Miles, and linked his family to South Africa and its people in a unique and personal way.

The founder of the firm, Miles' great grandfather, Benjamin Henry Blackwell, was described as "a modest and retiring person, whose underlying determination was to make synonymous the pursuits of success and excellence in his business. Throughout his life ... he tried 'to do justly love mercy and walk humbly with his God'” (Ricketts and Foster 2004: II). This courteous, self-effacing style was inherited by Miles. It appears to have been a feature of BHB from the time its doors were first opened in 1897.

Together with the modesty and reticence, there was a conscientious intention to be diligent and to serve. The 'continuing insistence on the highest standards of service' together with the 'transcendent capacity of taking trouble' (Ricketts and Foster 2004: II) impressed themselves on Blackwell's customers, including many generations of Oxford graduates. Norrington (1983: 4I) gave the following example:

In 1903, the first Rhodes Scholars arrived in Oxford, and were to have an important effect on export sales, especially, at first, in South Africa. Rhodes University in Grahamstown was founded in 1904, and the librarian's first thought was to write to Blackwells, which he had known as an undergraduate, asking if the firm could supply the needs of his library. Benjamin Henry Blackwell wrote back to say he would be delighted to see to it, and at the librarian's request the spine of each book was blocked with the words 'Rhodes University Library' before it left Oxford.

\section{Miles Blackwell and BHB}

Miles, like his father Richard, was educated at the Dragon School in Oxford, and then went on to Winchester College, after which he naturally proceeded to New College, Oxford. There he read history. Of particular interest to him was military history from Nelson's navy to the American Civil War. He could happily and fluently list the ships in Nelson's line of battle at Trafalgar, or discuss the strategic advantages of Stonewall Jackson's Wilderness campaign. His prodigious knowledge of a wide range of military campaigns was testimony to his leisure reading and his continuing fascination with history. Whenever he travelled he made a point of visiting places associated with British military history, which meant that in South Africa he would make time to visit sites of Anglo-Boer War or Zulu War battles.

Miles began his career with the family business of B H Blackwell Limited, (BHB), the Oxford-based bookseller, on 17th July, 1966. In 1969, his father, Richard, became Chairman of BHB and his grandfather, known to employees and family alike as 'The Gaffer', remained a significant presence in the running of the company. Later Miles was given responsibility for developing the international business of the firm, and as a result he travelled widely to all parts of the English-speaking world, but most notably to the Middle East, Australia and South Africa. As a result of his success, he became the company's first Sales and Marketing Director.

Miles was a very modest person and, like his Blackwell ancestors, self-deprecating and courteous to a fault. Again like his father and grandfather, he had a strong sense of duty and tradition. He was proud of being English and uncompromising in his patriotism. He was also diligent and trustworthy. In 1974, at the suggestion of Richard Abel himself, he was sent to Oregon to lead the team that worked out the financial plan for the takeover of the Richard Abel Company, creating Blackwell North America, Inc. (Norrington 1983: 172). This was a significant experience for Miles. The Richard Abel Company had invested heavily in library and vendor technology and Miles came to appreciate the value of that investment for future business. At the American Library Association (ALA) mid-winter conference in Chicago in 1975 he gave an impromptu speech to librarians and former Abel customers about the new company. His theme was that Blackwell had entered a new arena in bookselling, by teaming with the innovator of library technology, the Richard Abel Company, and merging it with an almost 100 year tradition of bookselling and customer care (Satisky 2009). Chris Tyzack noted that Miles was at heart a traditionalist but had a passion for the benefits that new technologies could bring (Tyzack 200 I). Blackwell North America (BNA) became a major player in world wide bookselling, surpassing B H Blackwell sales and, depending on swings in currency shifts between the dollar and sterling, gave libraries a choice of least expensive or earliest editions of joint US/UK editions.

On 26th February 1980, Miles' father Richard died in office aged 62. He was described as a very private person, reticent about self-disclosure, who respected such modesty in others. Miles too displayed similar modesty and reticence, combined with a mischievous sense of humour, a determined independence of thought and action, and a commitment to customer service and loyalty. Little was written about BH Blackwell during Miles' executive tenure, which in itself is characteristic of his modest and reticent style. However, this lack of evidence creates a problem for anyone wishing to document the growth of the company business during that period. Elements do emerge from contemporary publications. 


\section{The South African book trade in the 1980s}

During Miles Blackwell's tenure at the helm of the family business, as indicated above, librarians, and especially academic librarians experienced huge increases in the cost of books and journals. This situation was not peculiar to South African academic libraries. Similar experiences were noted elsewhere (see White 1989; SCONUL 1987). In South Africa, however, in 1984 and 1985, there was a significant drop in the value of the South African Rand on international currency markets, which exacerbated the situation. At the University of Cape Town the periodicals budget almost doubled in one year from R675,000 to RI.2 million (Hooper 1990a). Expectations of the library seemed to escalate with the journal price, especially in scientific, medical and engineering fields, as academics felt that their information sources were threatened. However, for South African librarians the combined price increase and the devaluation of the Rand added impetus to initiatives to promote collaboration, the development of shared collection development and more formal regional cooperative networks. Although significant progress had been made with the establishment of the South African Bibliographic and Information Network (SABINET), regional cooperation was seen as imperative (Kemp I996). Academic libraries in South Africa had become the de facto national research information system of the country.

Learning from the experience of colleagues in Europe and North America, especially in terms of using emerging computer technologies, became crucial. But with the squeeze on library budgets and the national currency unit, overseas visits were the first to be curtailed.

There can be little doubt that the most extensive library system in Africa, the most vibrant economy and, for all its failings, the most comprehensive education system in Africa at that time lay within the borders of South Africa. However, for those who were the purveyors of books and journals and the promoters of the free flow of information, a number of powerful and influential bodies endorsed or encouraged a book boycott of South African libraries and academic institutions. The immediate result was that some of those with book businesses in South Africa sold them to local buyers, while others stopped exporting books to South Africa (Hooper 1990b). The Danish government also passed a law (subsequently repealed) prohibiting trade with the Republic of South Africa and Namibia. Libraries in South Africa were inundated with letters from trading and exchange partners all over the world cutting off contacts. They had decided not to trade with any South African book dealer, library, university or school. The boycott was applied irrespective of the political stance of the institution being subjected to it. Parcels of books which did get through often had anti-South African slogans written on them by packers or handlers in their countries of origin.

The Association of American University Presses (AAUP) was the first US body to criticize the book boycott of South Africa. The AAUP statement of December 1987 concluded: 'We believe that books have no place in an embargo. The right of the oppressed to read and to learn is no less urgent than our need to learn about them and to learn from them' (Hooper 1990b). There can be little doubt that the Board of BH Blackwell must have debated the issue fully during that difficult time. Some might have argued along the lines of the AAUP above. Free trade would be good for European and American business as well as for the victims of apartheid. Promoting the free flow of information would do something positive and constructive to dissolve the historic scourge of apartheid in South Africa and create a new non-racial, democratic and just future. Whatever the outcome of the debates in the boardroom of BH Blackwell in Oxford, Miles was able to influence matters and support his customers and the integrity of the business. This concern for his customers and his service-orientation enabled Miles to build the family business up into an academic library supplier of books and journals that challenged other global players such as EBSCO, Swets and Zeitlinger, and Elsevier.

His customer support manifested itself in other ways as well. In 1984, under the leadership of Prof Piet Aucamp, then University Librarian at the Rand Afrikaans University (now the University of Johannesburg), a visit to several suppliers of computerised library systems in Europe and the USA was undertaken. Joining Prof Aucamp were Prof Casper Lessing, University of Potchefstroom, Tony Hooper, University of Cape Town and Hennie Viljoen, University of Stellenbosch. An expert in IT systems from Rand Afrikaans University, Prof Basie von Solms, was also part of the team.

Miles Blackwell was contacted and, despite possible consequences, kindly assisted the group in various administrative ways. The group was met at Heathrow airport and driven to Oxford. Accommodation and other support were made available. Visits to BHB were facilitated and a car was put at the disposal of the group to take them to the College of Librarianship, Wales, so that they might consult with academic colleagues who were monitoring developments in the United Kingdom. Companies in England, Wales and the United States were visited and their products evaluated. On the return trip, a final visit was paid to BHB and a round table discussion of early impressions and findings took place at Beaver House.

The way Miles and his colleagues at BHB handled the situation was evidence of his personal loyalty to his customers, and his determination to make sure that their needs were addressed. Clearly Miles believed that if he and BHB could meet the needs of the customers, it was the best way to demonstrate their business values and encourage continued customer loyalty. Furthermore, the outcome for the library profession in South Africa was an injection of expertise in, and 
commitment to, the use of integrated computer systems for enhanced library management. Like ripples in a pond, the impact spread outward to other libraries and greatly improved the speed and efficiency of library service provision to customers, as well as in the ordering, processing and administration of books and journals.

\section{The Blackwell Travel Bursary}

During that difficult time, as a result of the fluctuations in currency values, payments of accounts might have been delayed. Miles always had a deep understanding of the local circumstances and tried to make whatever accommodations were possible. Later, in July 1989, Miles and Chris Tysack met with Hennie Viljoen in Oxford. During lunch, at one of the picturesque pubs frequented by Miles outside Oxford, Hennie was asked about the financial situation in South Africa. Miles was concerned that libraries were experiencing major difficulties doing what was expecting of them. Of particular concern was the difficulty for librarians of travelling and attending professional meetings. Similar to other such initiatives in Canada and Australia, the BH Blackwell Travelling bursary was born.

Subsequently, in September 1989, the South African Institute for Librarianship and Information Science (SAILIS) held its annual conference in Kimberley. True to his sense of history, Miles chose to stay in the Kimberley Club. Started by Cecil John Rhodes, the Kimberley Club, during the siege of Kimberley in the Anglo-Boer War, maintained a supply of imported champagne and other foodstuffs against the inevitable day when the siege would be lifted (Packenham 1979). Incarcerated in Kimberley by the siege, an impatient and irascible Cecil John Rhodes made the Club his home, while making life difficult for Col Kekewich, the Officer Commanding Kimberley at the time. This historic aspect of the Kimberley Club was known to Miles and was the reason for his stay there.

One evening Miles, Peter May and Tony Hooper met in the Club. Miles presented his idea for a Blackwells funded scholarship to assist and encourage South African librarians to advance the standards of their profession. In a very quiet and low-pitched voice he expressed his wish that a sum of money be administered by a 'Gang of Five' senior librarians representative of the major institutions with which his firm did business. In essence this meant the heads of the major academic research libraries in the country. He needed guidance on what form the funding should take, and, because of the difficulty of ensuring supplies of books and journals, as well as of maintaining contacts with contemporary developments in Europe and the United States, the notion of a Travelling Scholarship moved closer to confirmation. Miles asked Hennie to act as convenor and chairman of the Scholarship Committee.

After his return to South Africa at the end of September from abroad, Hennie, in consultation with Miles, selected the members of the BHB Travelling Bursary Committee - the 'Gang of Five'. The members were

- Hennie Viljoen, University of Stellenbosch (Convenor)

- John Willemse, University of South Africa

- Piet Aucamp, Rand Afrikaans University

- Egbert Gerryts, University of Pretoria

- Tony Hooper, University of Cape Town

One travel bursary per year was offered and applicants were invited to compete for it. Rules for the award of the Bursary were drawn up and members of the library profession were invited through an announcement in the SAILIS Newsletter to apply for financial assistance to attend a meeting, or training course. Every candidate had to supply a personal resume and indicate the purpose and importance of their travel plans. Regular meetings of the Gang of Five were held to discuss and evaluate applications. Throughout the process of discussion and evaluation, Miles was not involved, preferring to leave control and decision-making to the Gang of Five. He was only informed about the names of the successful candidates, as a condition of the award was that the recipient should include a visit to BH Blackwell in Oxford as part of the itinerary. Professionals from all levels benefited from this financial assistance. It was clear that as from 1990, under the difficult financial circumstances, this support was of utmost importance to the recipients.

In retrospect, it has become clear that Miles had encouraged and funded a number of initiatives to promote librarianship in several countries. In Australia, he started the annual BH Blackwell Fieldwork Scholarship in association with Monash University (Awcock 200I). In Canada, the Canadian Association of College and University Libraries has established the Miles Blackwell Outstanding Academic Librarian Award. 'The Miles Blackwell Outstanding Academic Librarian Award is made to an individual member of CACUL whose contributions will continue and who can encourage and work with their colleagues' (Canadian Library Association 2008). Both these initiatives date back to 1987 or thereabouts, indicating that Miles at that time was considering ways of promoting academic libraries and librarianship in those countries where BH Blackwell had major business connections. Characteristically, he made his mark in a quiet and unobtrusive way, to ensure the greatest benefit for his customers and his 'chums' throughout the world, consistent with the highest business ideals of his forebears. His great-grandfather made it his business to 'serve the trade by which he lives'. Miles did the same - and it stood him in good stead. 
Over the period of its existence, the BH Blackwell Travel Bursary funded approximately 10 visits by South African librarians to Europe and America. In later years the BH Blackwell Travelling Bursary was offered through the British Council. From the germ of an idea, discussed by Miles and Chris Tyzack with Hennie Viljoen in a pub in Oxford in the summer of 1989, grew a broad base of BH Blackwell's support for the library profession in South Africa. In this regard, Miles Blackwell was a visionary and pioneer, contributing to both the library profession and, through them, to the people of South Africa.

\section{Miles and the Blackwell engagement in South Africa}

Miles' interest in and ability to relate to people from a wide range of backgrounds combined with his enjoyment of visiting the significant places in British history where the British Empire had been made. On one occasion Miles was taken by Professors Piet Aucamp, Casper Lessing and Hennie Viljoen to the site of the siege of Potchefstroom (during the First Anglo Boer War) - one of many little remembered quarrels between Boer and Brit in the late 19th century. Afterwards they went to a graveyard in which were buried women and children from one of the concentration camps set up by Lord Kitchener as part of his policy to deny Boer commandos support in their guerrilla war against British forces. Miles was deeply moved by what he saw and kept apologising, saying, in his inimitable way, 'I am so sorry. I am so sorry', mindful of the greater tragedy, and shamed by the historic events that had caused such pain to the forebears of his hosts.

Such interest, open-mindedness and compassion endeared him to the Afrikaans-speaking members of the South African library profession. They were particularly appreciative of his willingness to sit through endless presentations in Afrikaans at South African Library Association conferences without any apparent evidence of boredom. He seemed to have a rich inner life that sustained him at such times. It was not only Miles who suffered in this way. His mother, Marguerite, often accompanied him on overseas trips, especially in the early 1980s, and she, and later his wife Briony, together with Peter May and Don Satisky, all joined him, graciously supporting him in his stoicism, and his determination to present $\mathrm{BH}$ Blackwell in the best possible light.

Don Satisky (2009) described one of these conference experiences as follows:

My first visit to South Africa was to the South African Institute for Librarianship and Information Science (SAILIS) conference in Pretoria, along with Miles and Peter May. It was the most boring library conference I had ever been to. At that time, Blackwell's held no exhibits in the exhibit area as Miles thought we should set ourselves apart from other vendors. We would just attend the conference and listen to the endless speeches which, if in Afrikaans, none of us understood. We would attend various receptions and then travel the country, visiting libraries. I am not sure what part I had in changing this policy, but for my next 9 visits to the RSA Blackwell's had a booth at each SAILIS conference, and I don't think we ever looked back.

Whenever people who knew Miles speak about him, certain characteristics of his personal style emerge. Firstly, his generosity and hospitality were experienced by people from all over the world. He would often entertain his library 'chums' to lunch at a pub, or have them round to his home in Tubney so that Briony could be part of the occasion. Marguerite also participated by showing visitors around Oxford and Blenheim Palace.

Besides Briony and Marguerite, Miles would enrol senior members of Blackwell's staff. In 1984, during the visit to Oxford by Piet Aucamp and the rest of the South African team mentioned above, Bernard Roberts, Chris Tyzack, Alan Smith, John Merriman, and Peter May were tasked with taking the visitors to dinner in Fyfield followed by post-prandial beverages at Dry Leas. Miles knew his guests from many similar social occasions and thoughtfully arranged transport home for his 'front-line troops'. Similarly, after a dinner with Miles and Briony, arrangements were made for a taxi to collect the guests and ensure their safe return to their apartments. Such arrangements were often much appreciated by the recipients of such fulsome hospitality. Hennie Viljoen recalls:

One beautiful summer evening I had dinner in Tubney with Miles and Briony. At 10.30pm we were sitting in the garden having a last sherry. Then Bryony got up, went inside and when she returned Miles was telling me a story. She waited until he finished and said to him: 'Dear, the taxi is here.' It was so typical of Miles to care for his guests.

Peter May (2009) records the occasion when the mischievous sense of humour and puckish determination to be independent manifested themselves. A group of people from the Peoples Republic of China were working at $\mathrm{BH}$ Blackwell in Oxford. 
The first contract with the Peoples Republic of China after the burning of the books ... was worth - I think about US\$17 million. Miles was responsible for bringing that contract on board ... In the contract there was a clause that stated that two students from one of the universities associated with this contract had to work with Blackwell's and get to know us ... So we took them on for six months. One evening at Fyfield Manor, Miles was talking to me and asked me 'Peter, do you think that the Chinese would like to go down to the coast at the weekend? Shall we take them out on my boat?'

I replied, 'Miles, you are not thinking. I am on an aeroplane. I am on a 747. I am due at the National University of Singapore.'

'Oh! In that case l'll ask your wife.'

You can just hear him saying it, can't you? I said, 'I know my wife so well. June is very shy. I don't honestly think she will want to come if I am not there.'

'I'll have 10 pence with you otherwise,' he said. So we shook hands and I watched him as he strode off with his long legs to the other end of Fyfield Hall to see June. You can detect the answer to what happened - I lost the bet. I have a photo at home of June and another couple - Briony was there - and there is a photo of a 747 going over in clear blue sky and Miles offering a toast to Peter as the plane went over.

Although he came across as quite a shy man, his friend and colleague, Chris Tyzack, described him as follows:

He would go into pubs that you or I would not venture into and within minutes strike up a conversation with the locals which was genuine and friendly and unmarked by any class barriers. He simply liked people and was interested in them and their opinions, and that shone through the accent and the dress (Tyzack 200I).

Miles not only avoided public speaking or public performances of any kind, he was very concerned about any hint of ostentation or self-glorification. However, he could control events in a remarkable and apparently uncharacteristic manner. Peter May (2009) recalls:

At the 1987 IFLA Conference held in Brighton, Blackwell's sponsored a Mozart evening for the delegates ... Of the 1800 librarians there, 1600 turned up. Afterwards, Miles found Seth Manaka and Grace Motsuane, and he said 'You must come along and have a meal with us.' ... In the restaurant, Miles then said to Seth 'Can you teach us Shosholoza?' So there we are, with Seth going through the first line - 'Shosholoza ...' And Miles says 'Stop!' and he would take control. So Seth stopped and all the Blackwell's people started to go 'Shosholoza ...' Now the reason it is a great story is that we were politely asked by the owner of the restaurant to leave. We were disturbing everyone by making too much noise.

Peter May recalled a conference in Grahamstown, in the early hours of the morning, when the late-stayers were beginning to burst into song; each person present was required to contribute vocally. Some were singing 'Sarie Marais' and other memorable and sing-able folksongs. Peter May sang 'Blue Suede Shoes' (which he does very well) and Don Satisky delivered the Gettysburg Address. Miles, who hated any form of public performance, in an honest and spontaneous expression of who he was, contributed 'Land of Hope and Glory' (May 2009). Perhaps this is an example of what Chris Tyzack referred to as Miles' 'strong sense of humour and uncompromising integrity' (Tyzack 200I).

But his inherited reticence was deep rooted. In the course of preparing this paper, the authors have been in touch with more than one recipient of Miles' largess. All have indicated that Miles did not want his sponsorship or support for their work to be known.

A last word from Don Satisky:

I called Miles after Briony died, and we spoke for almost an hour. I could tell that his end was near, and of course he died shortly thereafter ... He told me something to the effect that after the age of 60 life is not necessarily worth living, if you had accomplished what you want to accomplish in life. I think he had. I think it had ended, and was about to end further (Satisky 2009).

\section{Conclusion}

If nothing else this article does two things. It tells how Miles was true to his values and how he demonstrated those values and his integrity in the exercise of his office. Miles sought no personal glory. He sought to serve - especially his customers and his chums. He was very aware of the privilege he had enjoyed in life and in his business. He could integrate in his mind 
the history of the 'firm' of BHB and the times it lived though with his sense of his responsibility to his customers. His was an historic perspective of the company, its service ethic and the need for continuity. He was prepared to stand up against enormous political pressure from his peers in Europe and North America, and perhaps his fellow board members in BHB, to make sure that the channels of published information flow remained open to his customers in South Africa. It was what he and his family predecessors did. The value of books and information was what he believed in. His service to his customers in South Africa reflected the self-sacrificing service ethic that he understood to be the essence of the family firm which he had the great privilege of leading. It was his duty as a bookseller, as a manager and as a 'chum'. Miles lived the essence of his perception of what it meant to be an Englishman whose word was his bond. And he was able to convey that to the people in South Africa who were the descendants of those who had suffered at the hands of his fellow countrymen in the Boer War. In that, Miles could distinguish between self-serving political opportunism and personal integrity.

He did not see his colleagues in South Africa as venal, racist, exploitative representatives of an oppressive regime. They too had their integrity which manifested itself in the way they addressed their responsibilities. Miles was in close contact not only with the white establishment librarians, but also with Seth Manaka, Grace Motsuane, Kay Raseroka and other librarians from the black communities in Southern Africa. Their responsibility was to provide the information resources that were needed by the communities served by those libraries. The politics of the situation were not their battle. To play politics in that situation would have been in conflict with the duties for which they had been appointed. Miles believed in the value of the printed word and the value of information and communications technology in carrying the knowledge to the people who needed it. He knew that his South African customers - his 'chums' - were there to do their jobs to the best of their ability with limited resources and against the political demands of the rest of the world. He knew what they expected of him, and he knew what he needed to do to meet their expectations. He had no doubt about what it took to be himself, to live up to the highest values of being British - the values he had learned from his parents and grandparents and at Winchester and New College, Oxford. In so far as he could perceive the needs of his customers over the longer term, he made things happen and set in place the structures that supported his purpose.

In September 2011 it will be ten years since the deaths of Miles and Briony. The Tubney Charitable Trust which they established with a substantial endowment will begin to wind up its affairs. Other unnamed beneficiaries of their support continue to promote matters which were of concern to them. Miles' modesty and reticence live on in many ways, not least in the affection and memory of the many people he befriended or with whom he worked. He sought no large memorial. It was not his style. He would be content to know that those people who were important in his life had raised a glass to his memory and that the company that was so much part of his life should thrive as a result of the innovations he made and the strategy he initiated. He too contributed to the development of the new, post-apartheid South Africa by ensuring that the people who needed the enlightened word to become part of the global society, would have benefited by what he had done.

\section{References}

Awcock, FH. 200I. Obituary to Miles and Briony Blackwell. Australian Academic and Research Libraries, 32(4). [Online]. http:// www.alia.org.au/publishing/aarl/32.4/obituaries.html. (Accessed I 3 March 2009).

Canadian Library Association. 2008. Advertisement for the Miles Blackwell Outstanding Academic Librarian Award. [Online]. http://www.cla.ca/AM/Template.cfm?Section=Miles_Blackwell_Award_for_Outstanding_Academic_Librarian. (Accessed I3 March 2009).

Hooper, ASC. 1990a. Overlapping journal subscriptions as a factor in university library cooperation. South African Journal of Librarianship and Information Science, 58(I): 25-32.

Hooper, T. 1990b. The case against the South African book boycott. Logos, I(3): 6- I3.

Kemp, G. 1996. Networking in South Africa. Bulletin of the American Society for Information Science, 22(6): 26-27.

May, P. 2009. Personal interview with Tony Hooper. Loughborough, UK. I8 March 2009.

Norrington, ALP. 1983 Blackwell's 1879 - 1979 - The history of a family firm. Oxford; B H Blackwell Ltd.

Packenham, T. 1979. The Boer War. London; Weidenfeld and Nicholson.

Ricketts, R. \& Foster, M. 2004. Blackwell's - a family firm for five generations. Oxford; Blackwell's History and Archive Project and Blackwell's Book Services.

Satisky, D. 2009. Personal email to Tony Hooper, I I September 2009.

Standing Conference on National and University Libraries (SCONUL) 1987. Changes in patterns of expenditure. (Doc 87//4I). London; SCONUL.

Tyzack, C. 200I. Obituary to Miles and Briony Blackwell. Australian Academic and Research Libraries, 32(4). [Online]. http:// www.alia.org.au/publishing/aarl/32.4/obituaries.html. (Accessed I 3 March, 2009).

White, H. 1989. Trouble at the OK Corral University Library. Library Journal, (September II): I54-I55. 